\title{
Impact of different aspects of social participation and social capital on smoking cessation among daily smokers: a longitudinal study
}

\author{
M Lindström, S-O Isacsson, S Elmståhl, The Malmö Shoulder-Neck Study Group
}

Tobacco Control 2003;12:274-281

See end of article for authors' affiliations

Correspondence to: Dr Martin TA Lindström, Department of Community Medicine, Malmö

University Hospital, Lund

University, S 20502

Malmö, Sweden;

martin.lindstrom@

smi.mas.lu.se

Received

28 January 2003

Accepted 23 June 2003

\begin{abstract}
Objective: To investigate differences in different aspects of social participation and social capital among baseline daily smokers that had remained daily smokers, become intermittent smokers, or stopped smoking at one year follow up.

Design/setting/participants/measurements: 12507 individuals, aged 45-69 years, interviewed at baseline between 1992 and 1994 and at a one year follow up were investigated in this longitudinal study. The three groups of baseline daily smokers were compared to the reference population (baseline intermittent smokers and non-smokers) according to different aspects of social participation and social capital. A multivariate logistic regression model was used to assess differences in different aspects of social participation and social capital.

Results: The baseline daily smokers that remained daily smokers at the one year follow up had significantly increased odds ratios of non-participation in study circles in other places than at work, meeting of organisations other than unions, theatre/cinema, arts exhibition, church, sports events, large gatherings of relatives, and private parties compared to the reference population. The baseline daily smokers that had become intermittent smokers at the one year follow up had significantly increased odds ratios of non-participation in church services. The baseline daily smokers that had stopped smoking had increased odds ratios of non-participation in having attended a meeting of organisations other than labour unions during the past year, having been to a theatre or cinema, and of having visited an arts exhibition during the past year. All three categories of baseline daily smokers had significantly decreased odds ratios of non-participation in night club/entertainment.

Conclusions: The baseline daily smokers that had remained daily smokers at the one year follow up had particularly high rates of non-participation compared to the reference population in both activities specifically related to social capital, such as other study circles, meetings of organisations other than labour unions, and church attendance and cultural activities such as theatre/cinema and arts exhibition, although significantly lower participation in cultural activities and meetings of other organisations was also observed among daily smokers that had stopped smoking. All three baseline daily smoker groups had higher rates of having visited a night club during the past year.
\end{abstract}

social anchorage, instrumental support, and emotional support indices..$^{13}$

Social participation is a specific concept, ${ }^{15}$ which can be interpreted either in social science terms of diffusion of information ${ }^{16}{ }^{17}$ and the contact with the norms, rules, values and control of society, ${ }^{17}$ or in psychosocial and psychological terms theoretically ${ }^{11}{ }^{12}$ connected with emotional and practical (instrumental) support. The lack of association between social support and smoking cessation makes the social science interpretation more plausible. Social participation is a key notion within the social capital literature. ${ }^{17-20}$ Social capital and social participation are of great importance for health related behaviours such as tobacco smoking because they may promote rapid transmission of health information, adaptation of health behaviour norms, and social control over deviant health related behaviours. Social participation is an empirically directly observable aspect of social capital that can be measured as either the density of organisations in a geographic area (the number of organisations and the number of members in these organisations in relation to the population size of that area), or by asking respondents to what shoulder-neck study 
extent they are engaged in formal and informal social activities. ${ }^{17}$ However, the social participation index variable used in the previous Malmö studies includes both formal/ organisational (study circle/course at workplace, other study circle course, union meeting, meeting of other organisations, church) and informal/private (night club entertainment, large gathering of relatives, private party) aspects of social capital as well as cultural activities (theatre/cinema, arts exhibition) and other social and civic activities (sports event, submitting a letter to the editor of a newspaper/journal, demonstration). The investigation of individual social participation and cultural participation factors that facilitate the process of smoking cessation thus seems to be of high priority.

Intermittent, non-daily smoking seems to be a transitional stage for many smokers. It is also related to a stronger intention to quit and a greater likelihood of having recently attempted to quit. ${ }^{21} 22$ The baseline daily smokers that had become intermittent smokers at the one year follow up will consequently be analysed separately.

The aim of this longitudinal study is to assess the importance of different aspects of baseline social participation on the inclination among baseline daily smokers to either continue as daily smokers, become intermittent smokers, or stop smoking. The second assessment of the smoking status was conducted at one year follow up.

\section{METHODS}

\section{Study population}

This study is based on the Malmö shoulder-neck study (MSNS), which is a subcohort of the Malmö diet and cancer study (MDCS). Malmö is a city in southern Sweden with approximately 250000 inhabitants. In 1990 all subjects born from 1926 to 1945, aged 45-69 years, and living in Malmö were defined as a cohort $(n=53325)$ for the MDCS. The recruitment to the MDCS took place from March 1991 until September 1996. The MSNS took place between February 1992 and December 1994, and included 14555 subjects (6489 men and 8066 women) from this cohort. Detailed information concerning the MSNS and the MDCS is given in two other articles. ${ }^{23}{ }^{24}$ The study cohort was approached in two ways: by postal invitation or, to a much lesser extent, by direct contact taken by the persons to be examined after a media campaign. The focus in the information given in the invitation was on the relation between diet and cancer and not on smoking or musculoskeletal problems.

All who participated in the MSNS baseline study were also invited to participate in a second examination one year later (median 12.6 months, interquartile range 12.3-13.3 months). A questionnaire was sent to all participants in the baseline study still registered in the municipality of Malmö. Information letters introduced the questionnaire, and two written reminders and finally a telephone call followed, if needed. In total 12507 participated in the second examination giving a response rate of $86 \%$. On their return, the questionnaires were immediately checked for missing values and completed by telephone, if necessary.

\section{Definitions}

\section{Outcome variable}

The smoking item in both the baseline and the one year follow up questionnaires contained four alternatives: daily smoker, intermittent (non-daily) smoker, stopped smoking, and never smoked (the two latter categories defined as non-smokers). The baseline daily smokers had at the one year follow up either remained daily smokers (daily/daily), become intermittent smokers (daily/intermittent), or had stopped smoking (daily/stopped).

The smoking item includes cigarette, cigar, and pipe smoking, but the vast majority $(80.9 \%$ of all men and $97.3 \%$ of all women) were cigarette smokers.
The reliability of the smoking item was assessed by investigating the test-retest stability of 200 respondents within two weeks after the baseline examination. The test-retest stability was very high. The $\kappa$ coefficient was 0.96 for all 200 respondents, 0.99 for the men and 0.94 for the women. No age differences in reliability were observed, since the $\kappa$ coefficients for the smoking item was 0.97 for the $<58.1$ year group and 0.96 for the $>58.1$ year group.

\section{Independent variables}

The age of the participants was computed from birth to the first visit to the Malmö Diet and Cancer Study Center and categorised in five groups.

Country of origin-All participants born in other countries than Sweden were merged into a single category.

Marital status-Four categories were used: married (including persons cohabitating), never married, divorced, and widow/ widower.

Education-Education was categorised by length of education. The respondents were classified into three groups: university degree, medium level (university studies without degree or less than three years of university studies, senior high school), and basal level (primary school, nine years or less).

Oral snuff-Nicotine consumption in the form of oral snuff is a common habit in Sweden. The prevalence of snuff intake (yes/no) was assessed.

Social participation-Social participation (during the past year) describes how actively the person takes part in the activities of formal and informal groups as well as other activities in society. The questions concerned whether the respondents had participated in the following activities or not during the past year:

$$
\begin{aligned}
& \text { - study circle/course at workplace } \\
& \text { - other study circle/course } \\
& \text { - union meeting } \\
& \text { - meeting of other organisations } \\
& \text { - theatre/cinema } \\
& \text { - arts exhibition } \\
& \text { - church } \\
& \text { - sports event } \\
& \text { - letter to the editor of a newspaper/journal } \\
& \text { - demonstration } \\
& \text { - night club/entertainment } \\
& \text { - large gathering of relatives } \\
& \text { - private party } \\
& \text { - none of these activities during the past year. }
\end{aligned}
$$

Each of the social participation items/variables are thus dichotomous ("yes, participated", or "no, did not participate" during the past year).

The reliability of the different social participation items has been assessed by testing the test-retest stability of 200 respondents in the MSNS study. The test-retest stability of most of the items was reasonably high. The $\kappa$ coefficients were 0.63 for study circle at work, 0.70 for other study circle, 0.88 for union meeting, 0.63 for other meeting, 0.81 for theatre/ cinema, 0.80 for arts exhibition, 0.85 for church, 0.69 for sports event, 0.88 for writing and submitting an article to a newspaper/journal, 0.80 for demonstration, 0.63 for night club/entertainment, 0.70 for large gathering of relatives, and 0.51 for private party.

\section{Statistics}

Three groups of baseline daily smokers that either had remained daily smokers, had become intermittent smokers, or 


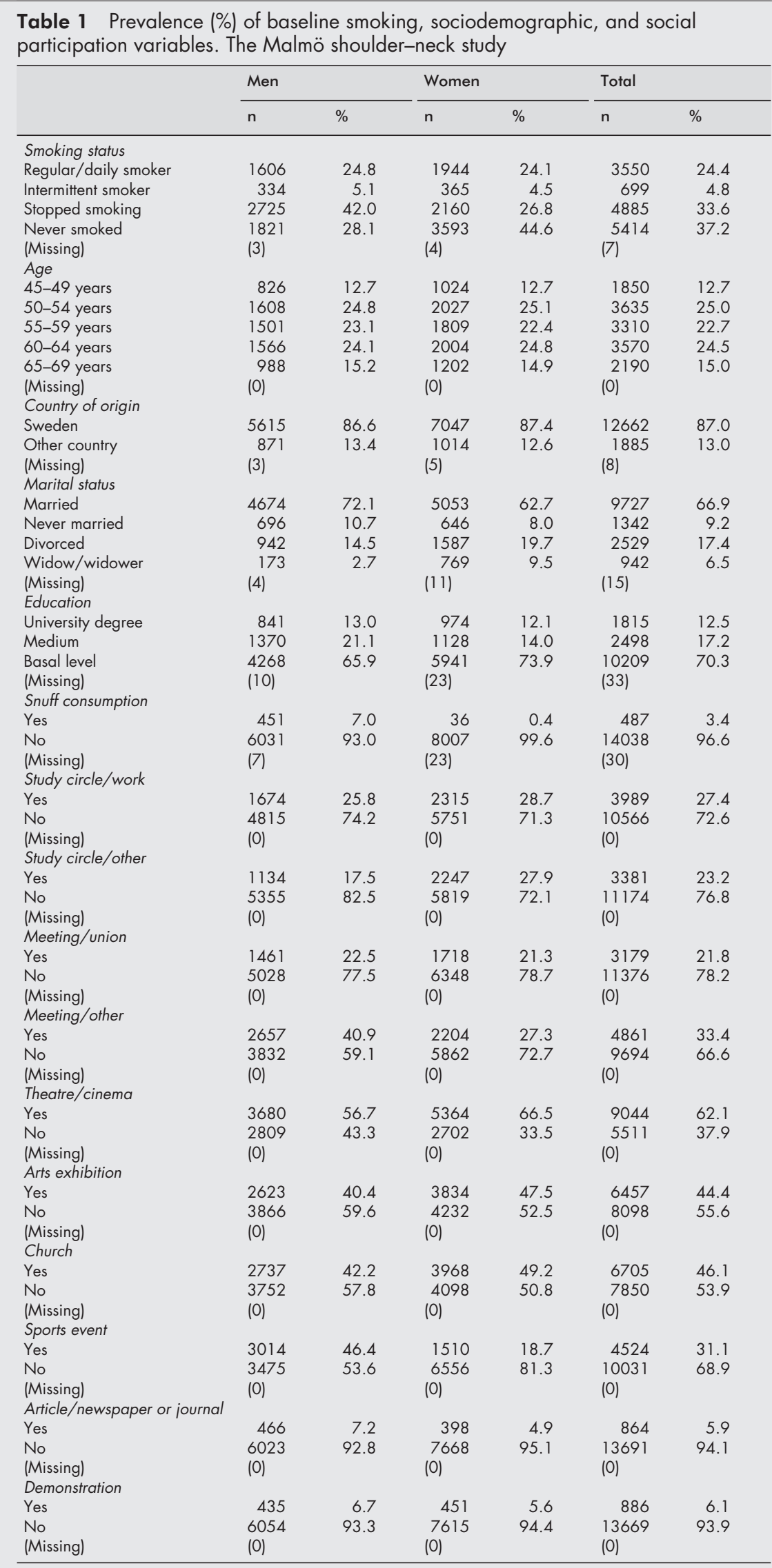


Table 1 continued

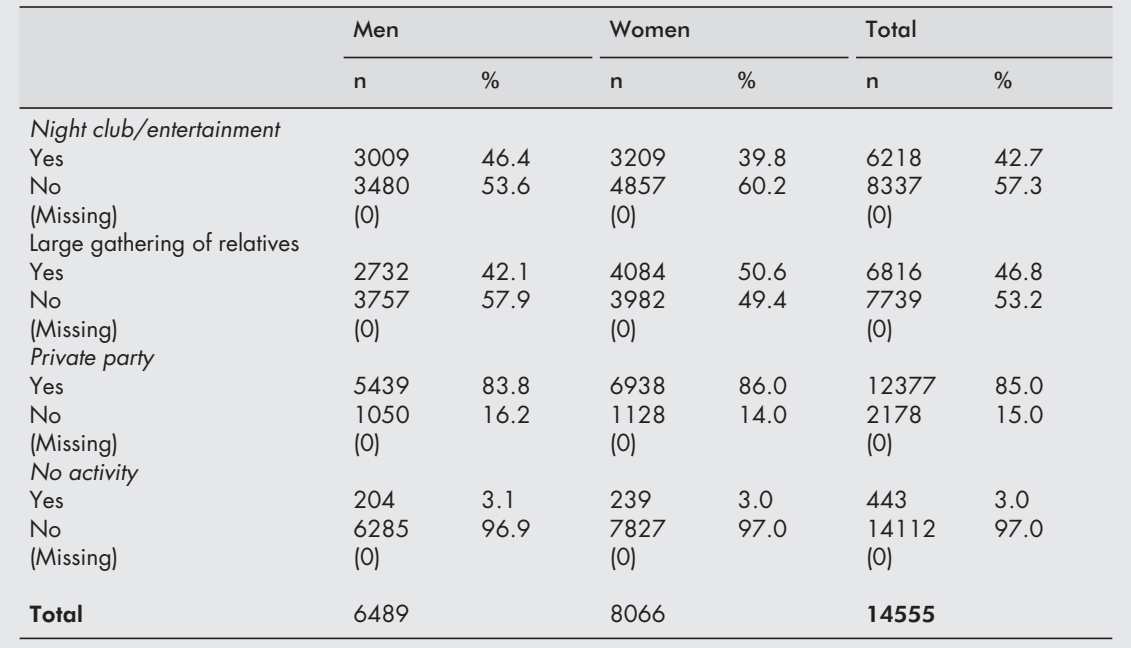

\begin{tabular}{|c|c|c|c|c|}
\hline & $\begin{array}{l}\text { Daily/daily } \\
(\mathrm{n}=2569)(\%)\end{array}$ & $\begin{array}{l}\text { Daily/intermittent } \\
(\mathrm{n}=193)(\%)\end{array}$ & $\begin{array}{l}\text { Daily/stopped } \\
(n=215)(\%)\end{array}$ & $\begin{array}{l}\text { Reference population } \\
(\mathrm{n}=9530)(\%)\end{array}$ \\
\hline \multicolumn{5}{|l|}{ Study circle/work } \\
\hline $\begin{array}{l}\text { No participation } \\
\text { (Missing) } \\
\text { Study circle/other }\end{array}$ & $\begin{array}{l}73.5 \\
(0)\end{array}$ & $\begin{array}{l}69.9 \\
(0)\end{array}$ & $\begin{array}{l}71.4 \\
(0)\end{array}$ & $\begin{array}{l}71.6 \\
(0)\end{array}$ \\
\hline $\begin{array}{l}\text { No participation } \\
\text { (Missing) } \\
\text { Meeting/union }\end{array}$ & $\begin{array}{l}81.7 \\
(0)\end{array}$ & $\begin{array}{l}76.7 \\
(0)\end{array}$ & $\begin{array}{l}77.9 \\
(0)\end{array}$ & $\begin{array}{l}74.7 \\
\text { (0) }\end{array}$ \\
\hline $\begin{array}{l}\text { No participation } \\
\text { (Missing) } \\
\text { Meeting/other }\end{array}$ & $\begin{array}{l}78.4 \\
(0)\end{array}$ & $\begin{array}{l}74.6 \\
(0)\end{array}$ & $\begin{array}{l}73.3 \\
(0)\end{array}$ & $\begin{array}{l}77.7 \\
\text { (0) }\end{array}$ \\
\hline $\begin{array}{l}\text { No participation } \\
\text { (Missing) } \\
\text { Theatre/cinema }\end{array}$ & $\begin{array}{l}71.8 \\
(0)\end{array}$ & $\begin{array}{l}69.9 \\
(0)\end{array}$ & $\begin{array}{l}73.7 \\
(0)\end{array}$ & $\begin{array}{l}64.0 \\
(0)\end{array}$ \\
\hline $\begin{array}{l}\text { No participation } \\
\text { (Missing) } \\
\text { Arts exhibition }\end{array}$ & $\begin{array}{l}48.2 \\
(0)\end{array}$ & $\begin{array}{l}39.9 \\
(0)\end{array}$ & $\begin{array}{l}40.1 \\
(0)\end{array}$ & $\begin{array}{l}33.2 \\
(0)\end{array}$ \\
\hline $\begin{array}{l}\text { No participation } \\
\text { (Missing) } \\
\text { Church }\end{array}$ & $\begin{array}{l}66.1 \\
(0)\end{array}$ & $\begin{array}{l}54.9 \\
(0)\end{array}$ & $\begin{array}{l}59.4 \\
(0)\end{array}$ & $\begin{array}{l}51.3 \\
(0)\end{array}$ \\
\hline $\begin{array}{l}\text { No participation } \\
\text { (Missing) } \\
\text { Sports event }\end{array}$ & $\begin{array}{l}64.3 \\
(0)\end{array}$ & $\begin{array}{l}58.5 \\
(0)\end{array}$ & $\begin{array}{l}54.4 \\
(0)\end{array}$ & $\begin{array}{l}50.3 \\
(0)\end{array}$ \\
\hline $\begin{array}{l}\text { No participation } \\
\text { (Missing) }\end{array}$ & $\begin{array}{l}72.1 \\
(0)\end{array}$ & $\begin{array}{l}65.8 \\
(0)\end{array}$ & $\begin{array}{l}64.5 \\
(0)\end{array}$ & $\begin{array}{l}67.6 \\
(0)\end{array}$ \\
\hline \multicolumn{5}{|c|}{ Article/newspaper or journal } \\
\hline $\begin{array}{l}\text { No participation } \\
\text { (Missing) } \\
\text { Demonstration }\end{array}$ & $\begin{array}{l}94.8 \\
(0)\end{array}$ & $\begin{array}{l}95.3 \\
(0)\end{array}$ & $\begin{array}{l}94.9 \\
(0)\end{array}$ & $\begin{array}{l}93.9 \\
(0)\end{array}$ \\
\hline $\begin{array}{l}\text { No participation } \\
\text { (Missing) }\end{array}$ & $\begin{array}{l}93.8 \\
(0)\end{array}$ & $\begin{array}{l}94.8 \\
(0)\end{array}$ & $\begin{array}{l}94.0 \\
(0)\end{array}$ & $\begin{array}{l}94.1 \\
(0)\end{array}$ \\
\hline \multicolumn{5}{|c|}{ Night club/entertainment } \\
\hline $\begin{array}{l}\text { No participation } \\
\text { (Missing) }\end{array}$ & $\begin{array}{l}53.6 \\
(0)\end{array}$ & $\begin{array}{l}47.2 \\
(0)\end{array}$ & $\begin{array}{l}50.7 \\
(0)\end{array}$ & $\begin{array}{l}57.8 \\
(0)\end{array}$ \\
\hline \multicolumn{5}{|c|}{ Large gathering of relatives } \\
\hline $\begin{array}{l}\text { No participation } \\
\text { (Missing) } \\
\text { Private party }\end{array}$ & $\begin{array}{l}57.6 \\
(0)\end{array}$ & $\begin{array}{l}54.9 \\
(0)\end{array}$ & $\begin{array}{l}51.2 \\
\text { (0) }\end{array}$ & $\begin{array}{l}51.6 \\
(0)\end{array}$ \\
\hline $\begin{array}{l}\text { No participation } \\
\text { (Missing) } \\
\text { No activity }\end{array}$ & $\begin{array}{l}18.3 \\
(0)\end{array}$ & $\begin{array}{l}17.1 \\
\text { (0) }\end{array}$ & $\begin{array}{l}11.1 \\
\text { (0) }\end{array}$ & $\begin{array}{l}13.1 \\
\text { (0) }\end{array}$ \\
\hline $\begin{array}{l}\text { No participation } \\
\text { (Missing) }\end{array}$ & $\begin{array}{l}95.3 \\
(0)\end{array}$ & $\begin{array}{l}96.4 \\
(0)\end{array}$ & $\begin{array}{l}97.7 \\
(0)\end{array}$ & $\begin{array}{l}97.9 \\
(0)\end{array}$ \\
\hline Total & 100.0 & 100.0 & 100.0 & 100.0 \\
\hline
\end{tabular}


Table 3 Odds ratios and 95\% confidence intervals (OR, 95\% Cl) of different aspects of lack of social participation among the three groups of daily smokers at baseline compared to the reference population at baseline. Men and women. The Malmö shoulder-neck study

\begin{tabular}{|c|c|c|c|}
\hline & $\begin{array}{l}\text { Daily/daily } \\
\text { (OR, 95\% CI) }\end{array}$ & $\begin{array}{l}\text { Daily/intermittent } \\
\text { (OR, 95\% CI) }\end{array}$ & $\begin{array}{l}\text { Daily/stopped } \\
\text { (OR, } 95 \% \mathrm{CI})\end{array}$ \\
\hline Study circle/work & $1.10(0.99$ to 1.21$)$ & $0.93(0.68$ to 1.26$)$ & 0.99 (0.74 to 1.34$)$ \\
\hline Study circle/other & 1.51 (1.35 to 1.69$)$ & $1.12(0.80$ to 1.56$)$ & $1.20(0.87$ to 1.65$)$ \\
\hline Meeting/union & 1.06 (0.95 to 1.17 ) & 0.85 (0.62 to 1.19$)$ & 0.80 (0.59 to 1.08 ) \\
\hline Meeting/other & $1.43(1.30$ to 1.57$)$ & 1.31 (0.96 to 1.78 ) & $1.60(1.16$ to 2.14$)$ \\
\hline Theatre/cinema & 1.88 (1.72 to 2.05$)$ & 1.34 (0.99 to 1.79 ) & 1.35 (1.02 to 1.77 ) \\
\hline Arts exhibition & 1.85 (1.69 to 2.02$)$ & $1.16(0.87$ to 1.54$)$ & 1.39 (1.06 to 1.83 ) \\
\hline Church & 1.78 (1.63 to 1.95$)$ & $1.40(1.05$ to 1.86$)$ & $1.18(0.90$ to 1.54$)$ \\
\hline Sports event & 1.24 (1.12 to 1.36$)$ & $0.92(0.68$ to 1.24$)$ & $0.87(0.66$ to 1.15$)$ \\
\hline Article/newspaper or journal & $1.19(0.98$ to 1.44$)$ & $1.34(0.68$ to 2.63$)$ & 1.23 (0.67 to 2.26$)$ \\
\hline Demonstration & $0.95(0.79$ to 1.14$)$ & $1.16(0.61$ to 2.20$)$ & $0.99(0.56$ to 1.75$)$ \\
\hline Night club/ entertainment & $0.84(0.77$ to 0.92$)$ & $0.65(0.49$ to 0.87$)$ & 0.75 (0.57 to 0.98$)$ \\
\hline Large gathering of relatives & 1.27 (1.17 to 1.39$)$ & $1.14(0.86$ to 1.52$)$ & 0.98 (0.75 to 1.28$)$ \\
\hline Private party & 1.49 (1.33 to 1.68$)$ & 1.37 (0.94 to 2.01$)$ & 0.83 (0.54 to 1.27$)$ \\
\hline
\end{tabular}

had stopped smoking at the one year follow up were compared to the reference population (intermittent smokers and all nonsmokers at baseline) in a logistic regression model according to the 13 different aspects of social participation at baseline. The odds ratios of non-participation in these 13 different social participation activities were calculated for the daily/daily, daily/ intermittent, and daily/stopped groups compared to the reference group (intermittent smokers and all non-smokers at baseline). A multivariate logistic regression model was used to assess differences in different aspects of social participation, adjusting for age, sex, country of origin, marital status, education, and snuff consumption. The statistical analysis was performed using the SPSS software package..$^{25}$

\section{RESULTS}

Table 1 shows that the proportions of daily and intermittent smokers at baseline were very similar among men and women. The proportion of never-smokers was much higher among women $(44.6 \%)$ than among men $(28.1 \%)$. On the other hand, the proportion of individuals that had stopped smoking was much higher among men $(42.0 \%)$ than among women $(26.8 \%)$. Men were married/cohabitating to a somewhat higher extent than women, and women were divorced and widows to a higher extent than men. On the other hand, a higher proportion of women also had only a basal level of education. Only $0.4 \%$ of all women were snuff consumers, compared to $7.0 \%$ of all men. The distribution according to age, country of origin, having participated in a study circle at work, a union meeting, having submitted an article to a newspaper/journal, having participated in a demonstration, night club/entertainment, and a private party did not differ between men and women. A higher proportion of men than women had participated in a meeting of any other organisation (than a labour union) and in a sports event during the past year. In contrast, a higher proportion of women than men had participated in a study circle other than at work, been to a theatre or cinema, visited an arts exhibition, been to church or been to a large gathering of relatives during the past year.
Table 2 shows that the group of baseline daily smokers that still smoked at the one year follow up had lower participation rates in many social activities compared to the reference population. They had a particularly high proportion of participants with no participation compared to the reference population in study circle other than at work ( $18.3 \% v 25.3 \%)$, meeting other than labour union meeting $(28.2 \% v 36.0 \%)$, theatre/cinema $(51.8 \% \vee 66.8 \%)$, arts exhibition $(33.9 \% v$ $48.7 \%)$, and having attended church (35.5\% v 49.7\%). The baseline daily smokers that had become intermittent smokers or had stopped smoking at the one year follow up did not differ to any larger extent from the reference population in any of the social activities. All three groups of baseline daily smokers (daily, intermittent or stopped smoking at the one year follow up) had somewhat higher participation rates during the past year in the night club/entertainment activity. Previously published data have shown that the baseline daily smokers who remained daily smokers at the one year follow up to a significantly higher extent than the total population were relatively young, born in countries other than Sweden, were not married, and had a lower educational level. They were also snuff consumers to a lower extent than the rest of the population. The daily smokers that had become intermittent smokers were not married/cohabitating and were snuff consumers to a much higher extent than the rest of the population. ${ }^{14}$

The results of the unadjusted analysis shown in table 3 show that the baseline daily smokers that remained daily smokers at the one year follow up had significantly increased odds ratios of non-participation in study circles in other places than at work, meeting of organisations other than unions, theatre/cinema, arts exhibition, church, sports event, large gathering of relatives, and private party compared to the reference population. The baseline daily smokers that had become intermittent smokers at the one year follow up had significantly increased odds ratios of non-participation in church services than the reference population. The baseline daily smokers that had stopped smoking had increased odds ratios of non-participation in having attended a meeting of other organisations than labour unions during the past year, 


\begin{tabular}{|c|c|c|c|}
\hline & $\begin{array}{l}\text { Daily/daily } \\
\text { (OR, } 95 \% \mathrm{Cl})\end{array}$ & $\begin{array}{l}\text { Daily/intermittent } \\
(\mathrm{OR}, 95 \% \mathrm{Cl})\end{array}$ & $\begin{array}{l}\text { Daily/stopped } \\
\text { (OR, } 95 \% \text { CI) }\end{array}$ \\
\hline Study circle/work & 1.11 (0.99 to 1.23$)$ & 0.96 (0.69 to 1.32$)$ & 1.04 (0.76 to 1.42$)$ \\
\hline Study circle/other & 1.50 (1.34 to 1.69$)$ & 1.12 ((0.79 to 1.57$)$ & 1.18 (0.85 to 1.64$)$ \\
\hline Meeting/union & 1.10 (0.99 to 1.23 ) & 0.91 (0.65 to 1.27$)$ & $0.84(0.62$ to 1.15$)$ \\
\hline Meeting/other & 1.37 (1.24 to 1.52$)$ & 1.26 (0.92 to 1.73$)$ & 1.63 (1.20 to 2.22$)$ \\
\hline Theatre/cinema & 1.90 (1.73 to 2.08$)$ & 1.40 (1.03 to 1.89 ) & 1.37 (1.03 to 1.83$)$ \\
\hline Arts exhibition & 1.83 (1.66 to 2.02 ) & $1.16(0.85$ to 1.56$)$ & 1.41 (1.05 to 1.88$)$ \\
\hline Church & 1.70 (1.56 to 1.87$)$ & 1.33 (0.99 to 1.79 ) & 1.12 (0.86 to 1.48$)$ \\
\hline Sports event & 1.26 (1.14 to 1.40$)$ & 1.00 (0.72 to 1.38$)$ & 0.97 (0.72 to 1.32$)$ \\
\hline Article/newspaper or journal & 1.14 (0.94 to 1.39 ) & $1.32(0.67$ to 2.60$)$ & 1.25 (0.68 to 2.32$)$ \\
\hline Demonstration & 1.00 (0.84 to 1.21$)$ & 1.21 (0.63 to 2.30 ) & 1.06 (0.60 to 1.87$)$ \\
\hline Night club/entertainment & 0.90 (0.82 to 0.99$)$ & 0.73 (0.54 to 0.98$)$ & 0.82 (0.62 to 1.08$)$ \\
\hline Large gathering of relatives & 1.22 (1.12 to 1.34$)$ & 1.11 (0.83 to 1.49$)$ & $0.94(0.71$ to 1.23$)$ \\
\hline Private party & 1.33 (1.18 to 1.50$)$ & 1.30 (0.88 to 1.91$)$ & $0.77(0.50$ to 1.18$)$ \\
\hline
\end{tabular}

All odds ratios in this table are adjusted for age, sex, country of origin, marital status, education, and snuff consumption.

having been to a theatre or cinema, and of having visited an arts exhibition during the past year, compared to the reference population. All three categories of baseline daily smokers had significantly decreased odds ratios of non-participation in night club/entertainment compared to the reference population.

Table 4 shows that the adjustment for age, sex, country of origin, marital status, education, and snuff consumption in the multivariate analyses did not affect any of the main results of the unadjusted analyses shown in table 3 .

\section{DISCUSSION}

The baseline daily smokers that had remained daily smokers at the one year follow up had particularly high rates of non-participation compared to the reference population in both activities specifically related to social capital such as other study circles, meetings of organisations other than labour unions and church attendance, and cultural activities such as theatre/cinema and arts exhibition. All three baseline daily smoker groups had higher rates of having visited a night club during the past year. The baseline daily smoker groups that had become intermittent smokers or had stopped smoking did not differ to the same extent from the reference population, although significantly higher rates of non-participation in meetings of other organisations, theatre/cinema and arts exhibition were also observed among daily smokers that had stopped smoking.

A comparison with another investigation conducted in the city of Malmö during the same time period with a higher participation rate showed a good correspondence in the same age groups concerning socioeconomic status, smoking, and social participation. ${ }^{13}$ The smoking prevalence is often somewhat higher among non-participants than among study participants. ${ }^{26}{ }^{27}$ This is confirmed in the MSNS by the fact that the prevalence of daily smoking at baseline was $24.4 \%$ among all baseline participants, but only $23.8 \%$ among those $86 \%$ of the baseline participants who also participated at the one year follow up. ${ }^{14}{ }^{28}$ However, this is probably of less importance for the findings and conclusions of this study.

The validity of items assessing smoking has been analysed several times, and the results have consistently shown that self reported tobacco smoking is a valid and reliable way to measure smoking habits in a population. ${ }^{29-34}$ The test-retest stability of the smoking item within two weeks was very high, the $\kappa$ coefficient indicating an extremely high reliability. Differential misclassification is not likely to have been present. Nondifferential misclassification seems to be a problem of less importance in this study, since non-differential misclassification tends to attenuate true differences, and the main results of this study show clear differences between the daily smoker group and the reference population. The reliability and validity of the different social participation variables showed a good or acceptable validity and reliability.

Age, sex, country of origin, marital status, education, and snuff consumption could be confounders of the associations between the social participation variables and baseline daily smoking. Adjusting for these variables, however, only marginally affected the estimates.

The 7\% prevalence of snuff consumption among men may be regarded as low compared to the prevalence sometimes reported for Sweden. ${ }^{5}$ However, other unpublished data from Scania in southern Sweden reveal the same prevalence of snuff use as the one reported in this study.

The longitudinal study design may be considered the most important strength of this study.

Despite the very high reliability of the smoking item, two baseline daily smokers reported at the one year follow up that they had never smoked. However, the exclusion of these two baseline daily smokers yielded the same results in the statistical analyses.

A total of 56 persons who were not smokers (two never smokers and 54 that had previously stopped smoking) at baseline had taken up daily smoking at the one year follow up. This very small number and small proportion of a total of approximately 9000 non-smokers at baseline corresponds very 
well with the general notion that the age interval 45-69 years is not the primary age interval for the recruitment of new smokers.

Social participation is theoretically and conceptually an entity in its own right. The connection between social participation and health has been investigated by Baum and colleagues, ${ }^{15}$ for example. Social participation is related to both social capital ${ }^{17}$ and social support. ${ }^{35}{ }^{36}$ Social capital is often regarded as a contextual trait of society, ${ }^{1720}$ while social support is more of a factor which concerns conditions in the closer psychosocial environment of the individual. The interpretation of the results of this study could thus go in either direction, towards social science theories such as social capital and diffusion of innovations, or in the direction of social support and more psychosocial and psychological theories. A social science interpretation of the different social participation items stresses the information as well as the norms, rules, values, and control provided by social networks. A psychological or psychosocial interpretation of the social participation items stresses the theoretical connection within the psychosocial stress theory with the close emotional and practical support provided by a spouse or relatively close friends.

However, a previous study on the MSNS material clearly shows that the association between social participation and smoking/smoking cessation is isolated from social support index variables such as emotional support and instrumental support. ${ }^{14}$ Emotional support and instrumental support do not exhibit the same significant associations with daily smoking/ smoking cessation as social participation. These findings may be explained by the fact that the effects of strong emotional and instrumental support from a spouse or another close friend or relation on smoking habits and smoking cessation may heavily depend on whether this very close person is a smoker or not. Good social support may thus encourage either smoking cessation or smoking continuation. This is the rationale for discussing the social participation items in relation to theories such as social capital and diffusion of innovations. High levels of social participation may be viewed as a source of knowledge, innovation, and transmission of certain values that influence smoking behaviour and the process of smoking cessation. This notion is theoretically supported by both the theory of diffusion of innovations ${ }^{16}$ and the general social capital theory. ${ }^{17} 18$

The values transmitted by high levels of different aspects of social participation may of course either be such values that support the continuation of the daily smoking behaviour, or such values that initiate and enhance the process of smoking cessation. However, the relatively low prevalence of daily smoking in Sweden and in Scania in southern Sweden (less than $20 \%$ ) suggests that high levels of social participation facilitate the process of smoking cessation. It is also well known that the smoking prevalence has fallen both in Sweden $^{5}$ and in Scania ${ }^{37}{ }^{38}$ in recent decades. This assumption is to some extent supported by the results of the statistical analyses in this study. Low levels of such aspects of social participation that constitute the formal social networks and formal social activities within the social capital literature, such as study circles other than at the workplace, meetings of other organisations than labour unions, and having been to a service in church during the past year, are significantly associated with the continuation of daily smoking (being a daily/daily smoker in our longitudinal study). The same associations are observed for the two clearly cultural activities of having been to the theatre/cinema and having visited an arts exhibition during the past year. The high odds ratios of not having been to the theatre/cinema and an arts exhibition during the past year are in accordance with previous findings that cultural activities specifically promote good health. ${ }^{39-41}$ Significant but lower odds ratios are also yielded for having been to a sports event, a large gathering of relatives, and a private party during the past year in the analyses.
In contrast, having visited a night club during the past year seems to be an activity that is positively associated with the continuation of daily smoking behaviour. Night clubs obviously constitute social environments that transmit values concerning smoking behaviour that deviate from the smoking behaviour values that permeate other social networks and social activities. However, visits to night clubs were also significantly more common among both baseline daily smokers that had become intermittent smokers and baseline daily smokers that had stopped smoking at the one year follow up. Night clubs represent social environments that entail all kinds of smokers. Furthermore, significantly lower participation in cultural activities and meetings of other organisations was also observed among daily smokers that had stopped smoking.

There thus seems to be a difference between all baseline daily smokers and baseline non-smokers in cultural activities and meetings of other organisations. On the other hand, attending other study circles than at work, church, large gathering of relatives, and private party thus seem to be the most important predictors of smoking cessation for daily smokers in this study. The indirect comparison of baseline daily smokers that continued to smoke at the one year follow up with baseline daily smokers that stopped smoking during the year shows that especially activities in informal social networks such as a large gathering of relatives and a private party seem to be of importance for the smoking cessation process of daily smokers.

Finally, specifically civic activities, such as having participated in a demonstration or having submitted an article to a newspaper or a journal during the past year, are not associated with daily smoking or smoking cessation. Participating in demonstrations and submitting articles have also in previous unpublished analyses been observed to be, in contrast to other social activities, unrelated to other measures of public health such as self reported health.

The different aspects of social participation and social capital are analysed separately. This procedure and statistical design is motivated by the fact that the 13 different aspects of social participation entailed in the social participation index variable have relatively low bivariate correlations with each other. The highest correlation coefficient between any two items is $r=0.39$ between arts exhibition and theatre/cinema, $r=0.25$ between union meeting and study circle at workplace, $r=0.20$ between large gathering of relatives and going to church, $r=0.20$ between going to church and theatre/cinema, and $r=0.20$ between demonstration and union meeting. All other bivariate correlations are even weaker. ${ }^{42}$

The findings of this study have implications for smoking prevention. Informal social activities such as a large gathering of relatives and a private party, as well as more formal activities such as attending church service and other study circles than at work, are positively associated with smoking cessation among daily smokers. This implies that the promotion of formal and informal social networks is justified not only from a general public health perspective, but also from a specific smoking prevention perspective, although the promotion and support of informal social networks seem more difficult than the promotion of organisations. The issue of tobacco smoking in night clubs could be addressed by smoking prohibition in public places, which of course also would have direct implications for the public health issue of passive smoking in public places.

\section{CONCLUSION}

The baseline daily smokers that had remained daily smokers at the one year follow up had particularly low participation rates compared to the reference population in both activities specifically related to social capital such as other study circles, meetings of organisations other than labour unions and church attendance, and cultural activities such as theatre/ 


\section{What this paper adds}

Daily smoking and smoking cessation are affected by biological, psychological, and social factors. Social participation measured as an index variable containing items concerning social activities in meetings of organisations and labour unions, study circles, cultural activities, church, attending a private party, a large gathering of relatives, and some other activities has previously been shown to be one of the psychosocial factors. In this longitudinal study each one of the 13 items included in the social participation index variable are analysed separately in order to assess their individual importance for the continuation of daily smoking and smoking cessation, respectively. The results imply that no social participation in study circles of other organisations than at work, church, sports event, large gathering of relatives, and a private party were significantly associated with the continuation of daily smoking compared to the non-smoking and intermittent smoker reference population, while no social participation in meetings of other organisations than labour unions, theatre/cinema, and arts exhibition were significantly associated with both the continuation of daily smoking and smoking cessation.

cinema and arts exhibition, although significantly lower participation in cultural activities and meetings of other organisations was also observed among daily smokers that had stopped smoking. Attending other study circles than at work, church, a large gathering of relatives, and a private party thus seem to be the most important predictors of smoking cessation for daily smokers in this study. All three baseline daily smoker groups had higher rates of having visited a night club during the past year. The baseline daily smoker groups that had become intermittent smokers or had stopped smoking did not differ to the same extent from the reference population.

\section{ACKNOWLEDGEMENTS}

The study was financially supported by grants from the Swedish Medical Research Council (grant B93-27X-10428-01A), the Swedish Council for Social Research (grant 92-0098:0B), and from the Medical Faculty, Lund University.

\section{Authors' affiliations}

M Lindström, S-O Isacsson, S Elmståhl, The Malmö Shoulder-Neck Study Group*†‡, Department of Community Medicine, Malmö University Hospital, Lund University, Malmö, Sweden

*Also the Multidisciplinary Pain Clinic, Malmö University Hospital, Malmö, Sweden

†Also the Department of Occupational and Environmental Medicine, Lund University Hospital, Lund, Sweden

$\ddagger$ Also the National Institute for Working Life, Stockholm, Sweden

\section{REFERENCES}

1 Peto R, Lopez AD, Boreham J, et al. Mortality from tobacco in developed countries: indirect estimation from national vital statistics. Lancet 1992;339: 1268-78

2 Collishaw NE, Lopez AD. Prevalence of cigarette smoking in developing countries. Tobacco Control 1995;4:327.

3 Molarius A, Parsons RW, Dobson AV, et al. Trends in cigarette smoking in 36 populations from the early 1980s to the mid-1990s: findings from the WHO MONICA project. Am J Public Health 2001;91:206-12.

4 Wersäll JP, Eklund G. The decline of smoking among Swedish men. Int J Epidemiol 1998;27:20-6.

5 World Health Organization. Tobacco or health: a global status report. Geneva: WHO, 1997.

6 Jarvis MJ. A profile of tobacco smoking. Addiction 1994;89:1371-6.

7 Pomerleau OF, Pomerleau CS. Research on stress and smoking: progress and problems. Br J Addict 1991;86:599-604.

8 Gulliver SB, Hughes JR, Solomon L, et al. An investigation of self-efficacy, partner support and daily stresses as predictors of relapse to smoking in self-quitters. Addiction 1995;90:767-72.
9 Sanders D, Peveler R, Mant D, et al. Predictors of successful smoking cessation following advice from nurses in general practise. Addiction 1993;88: 1699-705.

10 Hajek $\mathbf{P}$, West R, Wilson J. Regular smokers, lifetime very light smokers and reduced smokers: comparison of psychosocial and smoking characteristics in women. Health Psychol 1995;14:195-201.

11 Selye $\mathbf{H}$. The general adaptation syndrome and the disease of adaptation. J Clin Endocrinol 1946;6:112-230.

12 Syme L. Control and health: a personal perspective. In: Steptoe A, Appels A, eds. Stress, personal control and health. Chichester: John Wiley and Sons, 1989.

13 Lindström M, Hanson BS, Östergren P-O, et al. Socioeconomic differences in smoking cessation: the role of social participation. Scand J Public Health 2000;28:200-8.

14 Lindström M, Isacsson S-O, The Malmö Shoulder Neck Study Group. Smoking cessation among daily smokers, aged $45-69$ years: a longitudinal study in Malmö, Sweden. Addiction 2002;97:205-15.

15 Baum F, Bush RA, Modra CC, et al. Epidemiology of participation: an Australian community study. J Epidemiol Community Health 2000:54:414-23

16 Rogers E. Diffusion of innovations. New York: The Free Press, 1983

17 Putnam RD. Making democracy work. Civic traditions in modern Italy. Princeton: Princeton University Press, 1993.

18 Putnam RD. Bowling alone. The collapse and revival of American community. New York, London: Simon and Schuster, 2000.

19 Woolcock M. Social capital and economic development: toward a theoretical synthesis and policy framework. Theory and Society 1998;27:151-208.

20 Woolcock $M$. The place of social capital in understanding social and economic outcomes. Canadian Journal of Policy Research 2001:2:11-17.

21 Hennrikus DJ, Jeffrey RW, Lando HA. Occasional smoking in a Minnesota working population. Am J Public Health 1996;86:1260-6.

22 Owen N, Kent P, Wakefield M, et al. Low-rate smokers. Prev Med 1995;24:80-4

23 Berglund G, Elmståhl S, Janzon L, et al. Design and feasibility. J Intern Med 1993;233:45-51.

24 Ektor-Andersen J, Isacsson S-O, Lindgren A, et al, the Malmö Shoulder-Neck Study Group. The experience of pain from the shoulder-neck area related to the total body pain, self-experienced health and mental distress. Pain 1999:82:289-95.

25 Norusis MJ. SPSS for Windows. Advanced statistics. Release 6.0. Chicago: SPSS Inc, 1993.

26 Boström C, Hallqvist J, Haglund BJA, et al. Socio-economic differences in smoking in an urban Swedish population. Scand J Soc Med 1993;21:77-82.

27 Criqui MH, Barret-Connor E, Austin M. Difference between respondents and non-respondents in a population-based cardiovascular disease study Am J Epidemiol 1978;108:367-72.

28 Lindström M, Isacsson S-O. Long-term and transitional intermittent smokers: a longitudinal study. Tobacco Control 2002;1 1:61-7.

29 Murray RP, Connett JE, Lauger GG, et al. Error in smoking measures: effects on relations of cotinine and carbon monoxide to self-reported smoking. Am J Public Health 1993;83:1251-6.

30 Tate JC, Pomerleau CS, Pomerleau OF. Pharmacological and non-pharmacological smoking motives: a replication and extension. Addiction 1994:89:321-30

31 Verkerk PH, Buitendijk SE, Verloove-Vanhorick SP. Differential misclassification of alcohol and cigarette consumption by pregnancy outcome. Int J Epidemiol 1994;23:1218-25

32 Steffensen FH, Lauritzen T, Sörensen HT. Validity of self-reported smoking habits. Scand J Prim Health Care 1995;13:236-7.

33 US Department of Health and Human Services. The health benefits of smoking cessation. A report of the Surgeon General, 1990. Rockville, Maryland: Public Health Service, Centers for Disease Control, Office on Smoking and Health, 1990. (DHHS Publication No (CDC) 90-8416.)

34 Wells AJ, English PB, Posner SF, et al. Misclassification rates for current smokers misclassified as nonsmokers. Am J Public Health 1998;88:1503-9

35 Rosenfeld ER. Social support and health status: a literature review. Adelaide, South Australia: South Australian Community Health Research Unit, 1997.

36 House J, Landis K, Umberson D. Social relationships and health. Science 1988;241:540-5

37 Lindström M, Sundquist J. Ethnic differences in daily smoking in Malmö, Sweden: varying influence of psychosocial and economic factors. Eur J Public Health 2002; 12:287-94.

38 Lindström M. Social capital and the miniaturization of community among daily and intermittent smokers: a population-based study. Prev Med 2003;36:177-84.

39 Johansson S-E, Konlaan BB, Bygren L-O. Sustaining habits of attending cultural events and maintenance of health: a longitudinal study. Health Promot Internation 2001;16:229-34

40 Konlaan BB, Bygren L-O, Johansson S-E. Visiting the cinema, concerts, museums or art exhibitions as determinant survival: a Swedish fourteen-year cohort follow-up. Scand J Public Health 2000;28:174-8.

41 Konlaan BB, Biörby N, Bygren L-O, et al. Attendance at cultural events and physical exercise and health: a randomised controlled study. Public Health 2000;1 14:316-9.

42 Lindström M. Social participation, social capital and socioeconomic differences in health-related behaviours. An epidemiological study (dissertation). Lund: Lund University, 2000. 